\title{
HUBUNGAN DUKUNGAN KELUARGA DENGAN MOTIVASI UNTUK SEMBUH PADA PASIEN KANKER YANG MENJALANI KEMOTERAPI DI RSU. IMELDA PEKERJA INDONESIA
}

\author{
Nataria Yanti Silaban ${ }^{1}$, Edisyah Putra Ritonga ${ }^{2}$ \\ Program Studi S-1 Keperawatan, Universitas Imelda Medan \\ Email: ${ }^{1}$ labanria@gmail.com, ${ }^{2}$ ediritonga87@gmail.com
}

\begin{abstract}
ABSTRAK
Kanker adalah proses perkembangan sel yang tidak biasa yang dapat menyerang jaringan sekitarnya dan menyebar ke berbagai organ tubuh yang jauh. Pasien kanker yang menjalani kemoterapi sering merasa pesimis dan beranggapan bahwa penyakitnya tidak dapat diatasi. Peran dukungan keluarga sangat penting mengatasi masalah tersebut sehingga pasien termotivasi untuk sembuh. Penelitian ini bertujuan untuk melihat dan mengetahui adanya hubungan yang signifikan antara dukungan keluarga dengan motivasi untuk sembuh pada pasien kanker yang menjalani kemoterapi di Rumah Sakit Umum Imelda Pekerja Indonesia Tahun 2021. Penelitian ini menggunakan desain deskriptif kolerasi dengan pendekatan pengamatan sewaktu (cross sectional), dengan populasi berjumlah 30 orang dan pengambilan sampel dengan metode non probability sampling menggunakan purposive sampling. Teknik analisa data dengan menggunakan analisa data univariate dan bivariate dengan taraf signifikan 95\% $(\leq 0,05)$. Hasil penelitian ini menunjukkan bahwa adanya hubungan yang signifikan antara dukungan keluarga dengan motivasi untuk sembuh pada pasien kanker yang menjalani kemoterapi dengan nilai $P=$ 0,000 $\pm \leq 0,05$ di Rumah Sakit Umum Imelda Pekerja Indonesia Tahun 2021. Berdasarkan hasil penelitian diharapkan kepada petugas kesehatan dan peneliti dapat memahami dan meningkatkan kualitas asuhan keperawatan dengan melibatkan keluarga untuk memotivasi pasien agar bersedia menjalani kemoterapi secara teratur di wilayah kerja Rumah Sakit Umum Imelda Pekerja Indonesia Tahun 2021.
\end{abstract}

Kata Kunci: Dukungan Keluarga, Motivasi, Kanker, Kemoterapi.

\section{ABSTRACT}

Cancer is the growth of abnormal cells that tend to attack the surrounding tissue and spread to other organs of the body that are far away. Cancer patients undergoing chemotherapy sometimes feel pessimistic that their disease cannot be overcome or cannot be cured, to reduce this pessimism family support is needed so that patients have the motivation to recover. Motivation to recover in cancer patients undergoing chemotherapy at The Imelda Indonesian Workers General Hospital in 2020. This study uses a descriptive correlation design with a cross-sectional approach, with a population of 30 people and sampling with non-probability sampling methode using purposive sampling. The data analysis technique used univariate and bivariate data analysis with a significant level of $95 \%(\leq 0.05)$. The results of this study indicate that there is asignificant relationship between family support and motivation to recover in cancer patients undergoing chemotherapy with $P$ value $=0.05$ at the Imelda General Hospital of Indonesian Workers in 2020. Based on the results of the study, it is expected that health workers and researchers can understand and improve the quality of nursing care by involving families to motivate patient to willing to undergoing chemotherapy regularly in the working area of the Imelda Indonesian Workers General Hospital in 2021.

Keyword: Family support, Motivation, Cancer, Chemotherapy.

\section{PENDAHULUAN}

Kanker adalah proses perkembangan sel yang tidak biasa yang dapat menyerang jaringan sekitarnya dan menyebar ke berbagai organ tubuh yang jauh. Pertumbuhan kanker terjadi karena perbanyakan sel yang tidak terkendali (Indiyatmo, 2015). Pertumbuhan kanker adalah sumber utama kematian di dunia ini, mewakili 8,2 juta kematian akibat penyakit pada tahun 2012 (Isfandiari, 2015). Seperti yang ditunjukkan oleh WHO, ada 6,25 juta korban pertumbuhan kanker di dunia ini setiap tahun dan selama 20 dekade terakhir, 9 juta orang telah menendang ember dari penyakit, dan $2 / 3$ dari kejadian ini terjadi di negara-negara yang menciptakan

Di Indonesia, penyakit yang tidak dapat dihindari pada populasi pada semua usia 
adalah $1,4 \%$ atau diperkirakan 347.792 orang pada tahun 2013. Ruang lingkup D.I. Yogyakarta memiliki tingkat kanker tertinggi, yaitu $4,1 \%$ dan korban infeksi di Jawa Tengah dan Jawa Timur juga merupakan daerah dengan jumlah korban penyakit terbanyak, yaitu sekitar 68.638 dan 61.230 orang (Kementrian Kesehatan RI, 2015).

Berdasarkan data Riset Kesehatan Dasar (Riskesdas, 2013), di Sumatera Utara penyakit kanker dengan prevalensi tertinggi yaitu kanker serviks sebesar $0,7 \%$ atau diperkirakan sebanyak 4.694 penderita dan kanker payudara sebesar $0,4 \%$ atau diperkirakan sebanyak 2.682 penderita (Infodatin, 2015). Di Rumah Sakit Umum Pusat H. Adam Malik merawat 22.257 pasien kanker, terbagi pada 20.337 rawat jalan, 1.559 rawat inap dan 361 Di IGD sepanjang tahun 2017.

Kegiatan dalam terapi tumor ganas yang biasa dilakukan adalah tindakan medis (medis procedure), radioterapi (cahaya) dan kemoterapi. Organisasi obat kemoterapi melalui vena lebih kuat untuk mencapai selsel keganasan yang telah bermetastasis ke jaringan yang berbeda (Fauziana, 2011).

Kemoterapi adalah pengorganisasian obat anti kanker kepada pasien yang diberikan melalui infus atau infus. Kemoterapi ditawarkan oleh metodologi yang ditetapkan oleh spesialis dan dilakukan tanpa henti. Takaran kemoterapi untuk setiap toleransi berbeda-beda sesuai dengan kondisi pasien dan jenis obat antikanker yang digunakan. Efek samping dari penyelidikan terkait menyatakan bahwa kemoterapi diberikan karena memiliki banyak keuntungan, seperti mencegah metastasis ke organ yang berbeda (Suyanto, 2017).

Kepatuhan menjalankan kemoterapi adalah pasien dapat mengikuti pengobatan dari awal sampai akhir dengan mematuhi segala instruksi yang diberikan selama menjalani pengobatan. Hasil pemeriksaan terkait menyatakan bahwa ada 3 faktor yang dapat mempengaruhi ketidakpatuhan terhadap program pengobatan, khususnya faktor karakter termasuk keyakinan dan keadaan antusias, faktor pengobatan termasuk kekambuhan pengobatan, efek samping dan biaya, dan faktor dari administrasi kesehatan seperti korespondensi tak berdaya dengan pekerja kesejahteraan.
Mengingat

konsekuensi dari

pemeriksaan penting lainnya, dinyatakan bahwa ada tiga faktor yang mempengaruhi konsistensi pasien dengan kemoterapi, khususnya elemen terkait ketenangan, pengobatan, dan bantuan sosial. Faktor bantuan sosial, termasuk dukungan keluarga (Suyanto, 2017). Kondisi dan terapi penyakit dengan kemoterapi juga dapat menimbulkan tekanan, sehingga mempengaruhi keadaan dan selanjutnya keadaan mental pasien sehingga dukungan keluarga sangat diandalkan untuk membangkitkan inspirasi pasien pertumbuhan ganas yang menjalani kemoterapi di klinik untuk mencapai status kesejahteraan yang lebih baik (Indiyatmo, 2015).

Dukungan keluarga merupakan faktor vital bagi seseorang yang sedang menghadapi masalah dan dapat membangkitkan semangat individu dalam menjalani terapi, misalnya pasien penyakit yang menjalani kemoterapi. Dukungan keluarga bisa berupa materi dan baik (Fauziana, 2011).

Liave dan Rosa, mengatakan keluarga adalah pendamping tersayang bagi pasien pertumbuhan ganas dalam memerangi infeksi. Dukungan keluarga pada pasien keganasan diharapkan dapat mengangkat psikologis dan jiwa hidup pasien (Wahyudi, 2015).

Rosa juga mengatakan kanker adalah penyakit keluarga, di mana setiap orang yang terkena penyakit juga akan mempengaruhi seluruh keluarga seperti gairah, mental, keuangan dan fisik (Sari, Dewi and Utami, 2012). Selain dukungan keluarga, semangat pasien untuk sembuh juga menambah kesembuhan penyakitnya. Inspirasi pasien dalam menjalani kemoterapi kanker adalah pekerjaan untuk memenuhi kebutuhan yang bermanfaat untuk menenangkan gejala, menekan perkembangan dan penyebaran penyakit, mengeluarkan daya tahan dan mendapatkan kepuasan pribadi yang unggul (Indiyatmo, 2015).

Berdasarkan penelitian yang dilakukan oleh (Saragih, 2010) yang berkaitan dengan peranan dukungan keluarga pada pasien kanker menghasilkan kesimpulan bahwa pentingnya dukungan situasional (antusias, moneter dan mendalam) dan adaptasi pasien (penyembunyian dan interupsi) untuk memperluas dukungan keluarga. 
Penelitian lain yang dilakukan oleh (Sari, Dewi and Utami, 2012) yang berkaitan dengan dukungan keluarga juga menyimpulkan bahwa terdapat hubungan yang signifikan antara dukungan keluarga terhadap motivasi pasien kanker dalam menjalani kemoterapi. Penelitian lain juga dilakukan (Suyanto, 2017) yang berkaitan dengan dukungan keluarga pada pasien kanker yang dikemoterapi juga menyimpulkan bahwa terdapat adanya hubungan dukungan keluarga yang signifikan.

Berdasarkan data yang diperoleh peneliti dari Sistem Informasi Rumah Sakit (SIRS) di Rumah Sakit Umum Imelda Pekerja Indonesia pasien dengan diagnosa medis kanker yang sedang menjalani kemoterapi per enam bulan terakhir kira-kira sebanyak 64 orang. Berdasarkan pemikiran dan latar belakang permasalahan di atas, maka penelitian ini ditentukan judul "hubungan dukungan keluarga dengan motivasi untuk sembuh pada pasien kanker yang menjalani kemoterapi di Rumah Sakit Umum Imelda Pekerja Indonesia pada tahun 2021.

\section{METODE}

Penelitian merupakan jenis kuantitatif dengan desain deskripsi korelasi korelasi yang bedrtujuan untuk mengidentifikasi hubunagan antara dukungan keluarga dengan motivasi untuk sembuh pada pasien kanker yang menjalani kemoterapi. Penelitian mulai dilakukan dari awal penyusunan proposal sampai penyusunan hasil penelitian pada bulan Januari s/d bulan April 2021 di Rumah Sakit Umum Imelda Pekerja Indonesia. Populasi penelitian ini adalah seluruh pasien yang terkena kanker yang menjalani kemoterapi di Rumah Sakit Umum Imelda Pekerja Indonesia Tahun 2021 sebanyak 64 orang dan jumlah sampel penelitian adalah 30 orang.

Tes pemeriksaan penting untuk item umum yang sedang diselidiki dan dianggap ditujukan untuk seluruh populasi. Secara keseluruhan, contoh adalah komponen masyarakat yang dipilih tergantung pada kapasitas mereka untuk mengatasinya. Jumlah tes dalam penyelidikan ini adalah 30 orang.

Penelitian ini memiliki dua variabel yaitu dukungan keluarga dan motivasi untuk sembuh. Definisi operasional dukungan keluaraga adalah dukungan yang diberikan kelurga kepada pasien kanker dengan pengobatan kemoterapi. Dukungan keluarga diukur menggunakan kuisoner dengan 12 pertanyaan. Sedangkan motivasi pasien adalah hasrat atau semangat dalam menjalani kemoterapi yang merupakan kegiatan pasien kanker untuk mengikuti kemoterapi sesuai jadwal yang ditentukan. Pengukuran motivasi diukur menggunakan kuisioner dengan 12 pertanyaaan.

Instrumen penelitaian ini menggunakan survei dengan pertanyaan tertutup karena jawaban yang tepat telah diberikan sehingga responden hanya memutuskan untuk tidak menjawab dengan kalimat mereka sendiri. Survei ini diberikan sebagai pertanyaan sebagai pertanyaan yang direkam sebagai hard copy kepada responden untuk memperoleh data. Instrumen penelitian ini menggunakan alat ukur kuesioner dengan 12 pertanyaan tentang dukungan keluarga dengan skor Sangat sering $=4$, Sering $=3$, Jarang $=2$, Tidak Pernah $=1$ dan pertanyaan tentang motivasi untuk sembuh 12 pertanyaan dengan skor Sangat Setuju $=4$, Setuju $=3$, Tidak Setuju $=2$, Sangat Tidak Setuju $=1$. Populasi dalam penelitian ini sebanyak 64 orang dan sampel sebanyak 30 orang. Metode sampling yang digunakan pada penelitian ini adalah purposive sampling dengan kriteria inklusi yaitu Pasien yang terkena kanker stadium II dan III yang sedang menjalani tindakan kemoterapi di Rumah Sakit Umum Imelda Pekerja Indonesia dan bersedia menjadi responden dan kriteria eksklusi yaitu Pasien yang terkena kanker droup out dari pengobatan kemoterapi dan tidak bersedia menjadi responden.

\section{Analisa Data}

Penelitian dengan metode analisa univariat dan analisa bivariat. Analisa univariat bertujuan untuk mnegetahui distribusi, frekusensi dan presentase tingkat dukungan keluarga dan tingkat motivasi pasien kanker mengikuti pengobatan kemoterapi. Analisa bivariat adalah untuk melihat hubungan antara dukungan keluarga dengan motivasi untuk sembuh pada pasien kanker dengan pengobatan kemoterapi. Peneliti menganalisis data menggunakan uji Chi Square dengan batas kemaknaan $\mathrm{p}=.<0.05$, (Ho ditolak) (Notoatmojo, 2010). 


\section{HASIL DAN PEMBAHASAN}

\subsection{Hasil}

Setelah dilakukannya penelitian dengan judul "Hubungan dukungan keluarga dengan motivasi untuk sembuh pada pasien kanker yang menjalani kemoterapi di Rumah Sakit Umum Imelda Pekerja Indonesia tahun 2021” terhadap 30 responden yang diambil dengan cara purposive sampling maka diperoleh hasil sebagai berikut:

\section{Analisa Univariat \\ Data Univariat}

Berdasarkan data karakteristik umur bahwa mayoritas responden yang interval usianya 41-50 tahun sebanyak 14 orang (47\%), sedangkan minoritas responden yang interval usianya 20-30 dan 31-40 yang jumlahnya sama-sama 8 orang $(27 \%)$. Data status pernikahan bahwa mayoritas responden berdasarkan status menikah sebanyak 23 orang $(77 \%)$ sedangkan minoritas responden berdasarkan status janda sebanyak 2 (7\%). Data pendidikan bahwa mayoritas responden berdasarkan pendidikan SMA sebanyak 13 orang $(43 \%)$, sedangkan minoritas responden berdasarkan pendidikan tidak sekolah sebanyak 0 orang (0\%). Data pekerjaan responden bahwa mayoritas responden berdasarkan pekerjaan swasta sebanyak 11 orang (37\%), sedangkan minoritas responden berdasarkan pekerjaan pegawai negeri sebanyak 3 orang $(10 \%)$. Data penghasilan Keluarga bahwa mayoritas responden berdasarkan penghasilan keluarga >Rp.1.500.000 sebanyak 17 orang (57\%), sedangkan minoritas responden berdasarkan penghasilan keluarga <Rp.1.000.000 sebanyak 2 orang (7\%). Data lama menderita bahwa mayoritas responden berdasarkan lama sakit 6 bulan-1 tahun sebanyak 19 orang (63\%), sedangkan minoritas responden berdasarkan lama sakit $<6$ bulan sebanyak 5 orang $(17 \%)$ dan data jenis kanker bahwa mayoritas responden berdasarkan jenis kanker Ca mamae dan NPC sama-sama sebanyak 10 orang $(33 \%)$, jenis kanker $\mathrm{Ca}$ recti dan $\mathrm{Ca}$ ovarium sebanyak 5 orang $(17 \%)$.

Tabel 1. Karakteristik Responden Penelitian

\begin{tabular}{|c|c|c|c|}
\hline \multirow[t]{2}{*}{ No } & \multirow[t]{2}{*}{ Data } & \multicolumn{2}{|c|}{$\begin{array}{c}\text { Kelompok } \\
\text { Intervensi } \\
(\mathbf{n}=\mathbf{3 2})\end{array}$} \\
\hline & & f & $\%$ \\
\hline \multirow[t]{4}{*}{1} & Usia & & \\
\hline & 20-30 Tahun & 8 & 26,7 \\
\hline & 31-40 Tahun & 8 & 26,7 \\
\hline & 41-50 Tahun & 14 & 46,7 \\
\hline \multirow[t]{4}{*}{2} & Status Pernikahan & & \\
\hline & Belum Menikah & 5 & 68.8 \\
\hline & Menikah & 23 & 76,7 \\
\hline & janda & 2 & 6,7 \\
\hline \multicolumn{4}{|c|}{$3 \quad$ Pendidikan } \\
\hline & SD & 2 & 6,7 \\
\hline & SMP & 7 & 23,3 \\
\hline & SMA & 13 & 43,3 \\
\hline & PT (Diploma/Sarjana) & 8 & 26,7 \\
\hline 4 & Pekerjaan & & \\
\hline & PNS & 3 & 10,0 \\
\hline & IRT & 10 & 33,3 \\
\hline & SWASTA & 11 & 36,7 \\
\hline 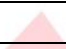 & Lain-lain & 6 & 20,0 \\
\hline \multirow[t]{4}{*}{5} & Penghasilan Keluarga & & \\
\hline & $<$ Rp.1.000.000 & 2 & 6,7 \\
\hline & Rp.1.000.000-1.500.000 & 11 & 36,7 \\
\hline & $>$ Rp.1.500.000 & 17 & 56,7 \\
\hline \multirow[t]{4}{*}{6} & Lama Menderita & & \\
\hline & $<6$ bulan & 5 & 16,7 \\
\hline & 6 bulan- 1 tahun & 19 & 63,3 \\
\hline & $>1$ tahun & 6 & 20,0 \\
\hline \multirow[t]{6}{*}{7} & Jenis Kanker & & \\
\hline & Ca mamae & 10 & 33,3 \\
\hline & NPC & 10 & 33,3 \\
\hline & Ca recti & 5 & 16,7 \\
\hline & Ca ovarium & 5 & 16,7 \\
\hline & Ca mamae & 10 & 33,3 \\
\hline
\end{tabular}

\section{Data Bivariat}

Tabel 2. Data Bivariat

\begin{tabular}{|c|c|c|c|c|c|c|c|c|c|c|}
\hline \multirow[t]{3}{*}{ No } & \multirow{3}{*}{$\begin{array}{l}\text { Dukungan } \\
\text { Keluarga }\end{array}$} & \multicolumn{8}{|c|}{ Motivasi Pasien Untuk Sembuh } & \multirow{3}{*}{$\begin{array}{l}\text { Asymp Chi- } \\
\text { Square }\end{array}$} \\
\hline & & \multicolumn{2}{|c|}{ Baik } & \multicolumn{2}{|c|}{ Cukup } & \multicolumn{2}{|c|}{ Buruk } & \multicolumn{2}{|c|}{ Total } & \\
\hline & & $\mathbf{n}$ & $\%$ & $\mathbf{n}$ & $\%$ & $\mathbf{n}$ & $\%$ & $\mathbf{n}$ & $\%$ & \\
\hline 1. & Baik & 23 & 76,7 & 1 & 3,3 & 0 & 0 & 24 & 80,0 & $\mathbf{0 , 0 0 0}$ \\
\hline 2. & Cukup & 2 & 6,7 & 3 & 10,0 & 0 & 0 & 5 & 16,7 & \\
\hline \multirow[t]{2}{*}{3.} & Buruk & 0 & 0 & 0 & 0 & 1 & 3,3 & 1 & 3,3 & \\
\hline & Total & 25 & 83,3 & 4 & 13,3 & 1 & 3,3 & 30 & 100,0 & \\
\hline \multicolumn{2}{|c|}{ Berdasarkan } & $\begin{array}{r}\text { tabel } \\
\text { baik }\end{array}$ & $\begin{array}{l}\text { diatas } \\
\text { dengan }\end{array}$ & & & $\begin{array}{l}\text { res } 1 \\
(77\end{array}$ & en & & $\begin{array}{l}\mathrm{k} \text { berj } \\
\text { luarga }\end{array}$ & $\begin{array}{l}\text { mlah } 23 \text { orang } \\
\text { lengan motivasi }\end{array}$ \\
\hline
\end{tabular}


responden yang cukup berjumlah 1 orang (3\%), dukungan keluarga dengan motivasi responden yang buruk berjumlah 0 orang $(0 \%)$. Dukungan keluarga cukup dengan motivasi responden yang baik berjumlah 2 orang (7\%), dukungan keluarga cukup dengan motivasi responden yang cukup berjumlah 3 orang (10\%), dukungan keluarga cukup dengan motivasi responden yang buruk berjumlah 0 orang $(0 \%)$. Dukungan keluarga buruk dengan motivasi responden yang baik berjumlah 0 orang $(0 \%)$, dukungan keluarga buruk dengan motivasi responden yang cukup berjumlah 0 orang $(0 \%)$, dukungan keluarga buruk dengan motivasi responden yang buruk berjumlah 1 orang (3\%).

Dari hasil analisis dengan menggunakan sistem SPSS uji Chi-Square menunjukkan bahwa adanya hubungan positif dan signifikan antara dukungan keluarga dengan motivasi untuk sembuh pada pasien kanker yang menjalani kemoterapi dengan hasil $\mathrm{p}<0,05$ atau $0,000<0,05$, jadi dapat disimpulkan $\mathrm{Ha}$ diterima bahwa ada hubungan bermakna antara dukungan keluarga dengan motivasi untuk sembuh pada pasien kanker yang menjalani kemoterapi di Rumah Sakit Umum Imelda Pekerja Indonesia tahun 2020.

Penelitian ini sejalan dengan penelitian (Indiyatmo, 2015) tentang Hubungan Antara Dukungan Keluarga Dengan Motivasi Untuk Sembuh Pada Pasien Kanker Yang Menjalani Kemoterapi Di Ruang One Day Care RSU Dr Moewardi dengan nilai korelasi sebesar 0,403 dan nilai probabilitas $0,000(P$-value $<0,05)$ dan (Sari, Dewi, and Utami, 2012) tentang Hubungan Dukungan Keluarga Terhadap Motivasi Pasien Kanker Payudara Dalam Menjalani Kemoterapi Di Ruang Cendrawasih I RSUD Arifin Achmad Provinsi Riau dengan nilai uji korelasi 0,008 ( $p$ value $<0,05$ ).

\subsection{Pembahasan}

\section{Dukungan Keluarga Pada Pasien Kanker Yang Menjalani Kemoterapi}

Berdasarkan hasil analisis, diperoleh sebagian besar pasien kanker yang mendapatkan dukungan tinggi dari keluarga 23 orang $(77 \%)$. Hal ini cenderung beralasan bahwa bantuan dari keluarga sangat penting bagi korban penyakit dalam menjalani kemoterapi, karena dapat menginspirasi pasien untuk menjalani kemoterapi.
Menurut (Nurpeni et al., 2013) Dukungan keluarga, khususnya pasangan/istri dapat memberikan perasaan senang, aman, tenteram dan bantuan yang penuh gairah akan mempengaruhi kesejahteraan emosional. Oleh karena itu, dukungan keluarga sangat diperlukan bagi pasien keganasan yang menjalani kemoterapi, untuk menambah semangat hidup atau inspirasi pada pasien penyakit yang menjalani kemoterapi.

Menurut ahli Onkologi Liave \& Rosa dalam (Trimbun News, 2011), Keluarga merupakan pendamping terdekat bagi pasien kanker dalam menghadapi perjuangan melawan penyakitnya. Dukungan keluarga terhadap pasien penyakit diharapkan dapat mengangkat psikologis dan jiwa hidup pasien. Menurut (Astri Fauziana, 2011), bahwa dukungan keluarga berpengaruh terhadap kesembuhan pasien penyakit, sehingga pasien kanker ganas yang menjalani kemoterapi dengan mendapatkan dukungan dari keluarga lebih semangat menjalani kemoterapi, dan ini dapat membantu kecepatan dalam meningkatkan sistem penyembuhan.

\section{Motivasi Pasien Kanker Dalam Menjalani Kemoterapi}

Hasil analisis dalam penelitian ini dapat diketahui bahwa sebanyak 25 (83\%) pasien kanker memiliki motivasi tinggi dalam menjalani kemoterapi. Hasil penelitian ini didukung oleh hasil penelitian (Astri Fauziana, 2011), bahwa dari 48 responden terdapat $31(64,6 \%)$ pasien ca mammae yang memiliki motivasi tinggi dalam menjalani kemoterapi.

Inspirasi merupakan ekspresi mental yang ditunjukkan melalui perilaku, dimana perilaku dipengaruhi oleh dukungan, baik dukungan positif maupun dukungan pesimis, cenderung dapat disimpulkan bahwa seseorang memiliki inspirasi yang tinggi dengan dukungan dari individu terdekat, terutama keluarga. Motivasi atau semangat hidup merupakan hal yang sangat penting bagi seseorang yang sedang menderita kanker khususnya pada pasien kanker sehingga mengharuskannya melakukan berbagai pengobatan seperti kemoterapi. Motivasi sendiri sebagai bentuk dorongan untuk melakukan sesuatu yang dikehendaki, dengan kata lain motivasi merupakan penyemangat yang timbul dari dirinya sendiri ataupun 
dengan bantuan pihak lain sebagai motivator bagi dirinya sendiri.

Inspirasi yang kuat dalam diri seseorang yang positif mengharapkan kesembuhan bahwa pasien akan menyelesaikan pengobatannya sesuai jadwal atau sesuai anjuran yang telah diberikan. Mengingat inspirasi yang kuat ini, pasien merasa sangat ingin melakukan pengobatan yang dibantu oleh dukungan mereka sendiri. Pasien kanker yang mendapat inspirasi besar sejak kemoterapi telah berubah menjadi kebutuhan bagi dirinya sendiri, khususnya kebutuhan akan rasa aman. Kemoterapi memberikan sertifikasi keamanan untuk kesejahteraan mereka karena kemoterapi adalah terapi yang harus dilalui oleh pasien dengan pertumbuhan ganas.

Motivasi luar biasa adalah motivasi ke dalam, secara eksplisit terdapat 25 orang (83\%) yang menyatakan bahwa motivasi pasien bahaya cukup dalam menjalani kemoterapi. Pasien yang memiliki motivasi luar biasa akan tabah menjalani kemoterapi. Hal ini sesuai dengan penelitian (Saragih, 2010) yang menyatakan bahwa peranan dukungan keluarga pada penderita yang mengalami kemoterapi berdasarkan emosional adalah baik.

\section{Dukungan Keluarga Dengan Motivasi Untuk Sembuh Pada Pasien Kanker Yang Menjalani Kemoterapi}

Hasil pemeriksaan yang dilakukan oleh para ilmuwan terhadap 30 responden menunjukkan bahwa semakin baik dan meluasnya dukungan keluarga maka semakin baik dan semakin meluas inspirasi untuk sembuh pada pasien penyakit yang mendapatkan kemoterapi. Tidak adanya dukungan keluarga pada pasien pertumbuhan maligna dapat membuat pasien tersebut kurang bersemangat untuk menjalani kemoterapi.

Dukungan keluarga tidak hanya jelas sebagai bantuan tulus, tetapi juga bantuan besar dan bantuan materi, dukungan keluarga juga dapat meringankan beban seseorang yang mengalami masalah dan memahami bahwa ada orang lain yang peduli. Dukungan keluarga memegang peranan penting dalam menangani masalah kesehatan dalam keluarga. Bantuan yang diberikan oleh keluarga dapat menumbuhkan keberanian dan meningkatkan motivasi pasien penyakit untuk melakukan kemoterapi. Menurut (Mutmainah dkk, 2013), melalui Dukungan keluarga yang besar dapat membuat individu menjadi lebih bebas dan positif tentang kapasitasnya sendiri (Aruan and Isfandiari, 2015). Melalui bantuan ini dapat membangun inspirasi dalam diri individu. Dukungan keluarga merupakan sudut pandang yang vital dan dasar dalam menentukan kecepatan sistem perbaikan yang dialami oleh pasien yang bersangkutan. Individu yang mendapat dukungan dari keluarganya akan membuat mereka merasa sangat dihargai, merasa bahwa keluarganya membutuhkan korban dan membutuhkan korban untuk selalu bersama keluarganya dalam melakukan berbagai aktivitas di dalam keluarga. Selanjutnya melalui bantuan ini dapat membujuk pasien untuk berusaha melawan penyakit yang dideritanya, kemudian pasien akan terinspirasi untuk berobat dan merasa dikuatkan dalam menjalani efek samping yang dirasakannya..

Hasil pada penelitian ini sesuai dengan hasil pada penelitian yang dilakukan oleh (Sari, Dewi and Utami, 2012), yang mendapatkan hasil dukungan keluarga berbanding lurus mempengaruhi motivasi penderita untuk berobat. Hasil pada penelitian ini juga sesuai dengan hasil penelitian pada penderita kanker payudara yang dilakukan oleh (Mutmainah dkk, 2013), hasil penelitian ini mendapati bahwa terdapat hubungan antara dukungan keluarga dengan motivasi untuk sembuh dari penderita kanker payudara. Sebagian besar responden mengatakan bahwa sudah mendapatkan dukungan penuh dari keluarga yang memotivasi mereka untuk segera sembuh. Oleh karena itu penderita kanker yang di kemoterapi merasa bahwa kesehatan dari dirinya sendiri adalah sebagai sebuah prioritas bagi keluarganya dan merupakan kebutuhan pokok bagi keluarganya.

Responden juga mengatakan bahwa, melalui dukungan sosial keluarga yang diterima oleh responden penderita kanker yang di kemoterapi memiliki dampak bagi penderita yakni menekan tingkat stres yang dialami pasca dinyatakan terdiagnosis kanker oleh dokter. Namun ketika mendengar motivasi dan melihat usaha maupun keterlibatan keluarga untuk memberikan dukungan bagi penderita untuk segera mendapatkan atau mencari pengobatan. Para penderita ini menjadi semangat kembali 
untuk segera mendapatkan pengobatan demi kesembuhan penyakit kanker yang sedang dialami.

\section{KESIMPULAN}

Berdasarkan hasil penelitian dan pembahasan, penelitian ini menyimpulkan bahwa ada hubungan dukungan keluarga dengan motivasi untuk sembuh pada pasien kanker yang menjalani kemoterapi. Saran penelitian khusunya kepada pelayanan kesehatan agar melibatkan keluarga dalam mendampingi pasien kanker yang menjalani kanker.

\section{REFERENCES}

Aruan, Kevin Patar, and Muhammad Atoillah Isfandiari. 2015. "Hubungan Dukungan Sosial Terhadap Pengobatan Kanker Payudara Di Yayasan Kanker Wisnuwardhana." Jurnal Promkes: The Indonesian Journal of Health Promotion and Health Education 3(2): 218-28. https://e-

journal.unair.ac.id/PROMKES/article/vi ew/4469 (August 26, 2021).

Astri Fauziana. 2011. "Hubungan Dukungan Keluarga Dengan Motivasi Menjalani Kemoterapi Pada Pasien Post Opca Mammae Di RS Kanker Dharmis Jakarta Barat."

Indiyatmo, Wahyudi. 2015. "Hubungan Antara Dukungan Keluarga Dengan Motivasi Untuk Sembuh Pada Pasien Kanker Yang Menjalani Kemoterapi Di Ruang One Day Care RSUD DR Moewardi." Jurnal Keperawatan 37: 110.
Kementrian Kesehatan RI. 2015. "Situasi Penyakit Kanker Indonesia." Pusat Data dan Informasi Kemenkes RI (2): 31-33.

Nurpeni, Ratih Khrisna Made, Ni Ketut Guru Prapti, and Ni Ketut Kusmarjathi. 2013. "Hubungan Dukungan Keluarga Dengan Tingkat Kecemasan Pada Pasien Kanker Payudara (Ca Mammae) Di Ruang Angsoka Iii Rsup Sanglah Denpasar.” Psychology Applied to Work: An Introduction to Industrial and Organizational Psychology, Tenth Edition Paul 53(9): 1689-99.

Saragih, Rosita. 2010. "Peranan Dukungan Keluarga Dan Koping Pasien Dengan Penyakit Kanker Terhadap Pengobatan Kemoterapi Di Rb 1 Rumah Sakit Umum Pusat Haji Adam Malik Medan Tahun 2010." : 1-10.

Sari, Mahwita, Yulia Irvani Dewi, and Agnita Utami. 2012. "Hubungan Dukungan Keluarga Terhadap Motivasi Pasien Kanker Payudara Dalam Menjalani Kemoterapi Di Ruang Cendrawasih I RSUD Arifin Achmad Propinsi Riau." Jurnal Ners Indonesia 2(2): 158-66.

Setiadi. 2007. Konsep Dan Penulisan Riset Keperawatan. Ed. 2. ed. Yogyakarta: Graha Ilmu. http://opac.depok.go.id:8123/inlislite3/o pac/detail-opac?id=16883.

Suyanto, Novi Pramesty Putri Arumdari. 2017. "Dukungan Keluarga Pada Pasien Kanker Yang Menjalani Kemoterapi Family Support in Cancer Patients with Chemotherapy." Fakultas Ilmu Keperawatan Universitas Islam Sultan Agung Semarang: 90-95. 